\title{
Trade unions' changing role: membership erosion, organisational reform, and social partnership in Europe
}

\section{Bernhard Ebbinghaus}

\section{Article by an MPIfG researcher}

Bernhard Ebbinghaus: Trade Unions' Changing Role: Membership Erosion, Organisational Reform,

and Social Partnership in Europe. In: Industrial Relations Journal 33(5), 465-483 (2002). Wiley-Blackwell - SSH

The original publication is available at the publisher's web site: http://dx.doi.org/10.1111/1468-2338.00248

Trade union movements in Europe are confronting multiple challenges. Among the adversities that union leaders face are pressing organisational problems: membership erosion due to structural changes in the economy and society; unfavourable political and institutional conditions that make organizing even more difficult; and attempts to attract and represent new social groups remain insufficient. 'Deunionisation' and its consequences for collective bargaining and for the political clout of union movements has become a problem acknowledged not only in academic but also in union circles. However, these accounts rarely note the intricate relationship between union movements and welfare states, and the potential consequences of ongoing efforts to recalibrate the welfare state, which unions helped expand.

Facing decline in membership, representativity, and dues income, we could expect unions to become more dependent on the welfare state in which they are embedded. Where they have institutionalized involvement in statutory workplace representation or play a role in the co-management of social and employment policies, they could gain additional legitimacy and resources. Where unions are weak in membership strength and bargaining power, they may still benefit from the bargaining coverage through better-organised employer organisations or from state support via legal extension of collective agreements to non-organised workers and non-unionised firms. In addition, the welfare state might provide several 'union securities', be it through union-friendly labour relations in the public sector or subsidies to collective insurance schemes run by unions. Moreover, as social movements, organised labour may be able to assume a role in the politics of welfare state reform, defending the interests of current and former wage earners against government and employer policies. In recent years, some union movements have been capable of blocking reform efforts, while in other cases, union leaders were willing to negotiate the adaptation of labour market and social policies to the current domestic and international challenges.

\footnotetext{
$\square$ Bernhard Ebbinghaus is Senior Researcher at the Max Planck Institute for the Study of Societies, Cologne.
} 
Comparative studies stressed the shift to bargaining decentralisation, labour market deregulation, and flexibilisation in production as major challenges to industrial relations in Europe since the 1980s (Baglioni and Crouch, 1990; Katz, 1993). Since the run up to European Monetary Union in the early 1990s, there have been attempts at negotiating long-term tripartite social pacts with the aim to achieve wage moderation under the pressures of international competition and stringent public budget constraints (Fajertag and Pochet, 2000; see also last year's review: Waddington, 2001). Moreover, in countries with social partnership traditions, the state delegated some public policy competencies to the social partners, in particular in labour market and social policy matters (Berger and Compston, 2002; Casey and Gold, 2000; Reynaud, 2000). With intensified European integration and the increased pressures on welfare states, a renegotiation of the post-war social compromise is on the agenda at both national and European levels. Also within the European Union, the 'open method of coordination' (see Goetschy in this issue), which relies on concerted national action that includes also the social partners, expanded from issues of employment to other social policy areas such as social inclusion and pension policies (de la Porte, 2001). Activities beyond wage bargaining have not been limited to the union side, as ideas of 'corporate social responsibility' and 'social partnership' are also discussed among employers at European level and especially in Anglo-Irish and Nordic circles in the recent years (Kjaergaard and Westphalen, 2001). Yet, in several European countries, employer representatives and political actors are also those that fiercely criticise and attempt to undo social partnership institutions-most prominently French employers and the Austrian centre-right coalition.

This year's annual review article focuses on the changing role of unions in the social policy area and the transformation of social partnership institutions against the background of continuing membership problems and organizational reforms of both trade unions and employer associations. The first section analyses the membership problems and representativeness of national unions. Arguing that unions are dependent on the institutional support of the welfare state, the comparative account concentrates on particular groups: the unemployed, public employees, women, older workers, and the young. The second section discusses recent organisational changes for trade unions and employers, looking at their declining representativeness, organisational changes and ambivalence towards social partnership. The final section discusses the changing role of social partnership, and its contradictory developments in recent years. Unions use their institutionalized involvement in social policy governance in order to advance their interests in the ongoing reform process. The retreat of state action from welfare policies has however also opened some new scope for bargaining, for instance, when unions become involved in negotiating occupational welfare benefits. However, some governments (following employer demands) have broken with past practices of facilitating social partnership, provoking opposition by the union movement. Pending political changes following the major elections of 2002 in several European countries, the balance of forces within the European Union may tilt towards a course unfriendly to partnership.

\section{Union membership and welfare state support}

\section{The trend toward deunionisation}

Over the last two decades, trade unions have been facing major difficulties in recruiting members. Since the 1980s, union density-the share of wage earners who are union members-declined in all but a few European countries (Ebbinghaus and Visser, 2000). Nevertheless, de-unionisation was more pronounced in OECD countries outside Europe, particularly North America, Japan and New Zealand (Golden, Wallerstein and Lange, 1999; Traxler, Blaschke and Kittel, 2001; Visser, 1991). Advocates of the 'European social model' therefore stress that collective forms of employment regulation-including higher levels of organisation among unions and employers-still distinguish the European Union (EU) from its global competitors, 
which have much weaker labour relations. Yet, this view tends to overlook the intraEuropean differences and the challenges to the model's sustainability (Ebbinghaus, 1999; Streeck, 1999). Increased problems to recruit union members and changing composition of its potential and actual membership pose major challenges to today's union movements in Europe as elsewhere.

Explanations for 'de-unionisation', the decline in union membership and density, as well as cross-national variations in 'union strength' have been manifold, stressing structural, cyclical, and institutional factors (Ebbinghaus and Visser, 1999; Wallerstein and Western, 2000). Long-term socio-economic changes make collective organisation more difficult: deindustrialisation and the growth of private services; white-collar, atypical, and part-time employment; changes in normative orientation from collectivism towards individualism. These secular changes, however, explain partially only the development over time, and they largely fail to account for cross-national variations (Ebbinghaus and Visser, 1999). In contrast to popular ideas about the negative impact of globalisation, increased trade, capital openness or direct investment have not uniformly led to deunionisation, instead, the 'fate' of unions is contingent on institutional mediating factors (Scruggs and Lange, 2002; Traxler et al., 2001). Moreover, unions are responding to these challenges by increasingly adopting recruitment drives and pooling resources via mergers (see the past reviews: Visser, 1998; Waddington, 2000, 2001). Thus, the verdict on the continuation of 'deunionisation' may still be out, and there is some room for hope.

Some observers have found solace in the fact that union movements in Nordic 'Social-Democratic' welfare states hold out better than many others outside and across Europe (Golden et al., 1999). Some entertain the view that in contrast to the deregulated 'liberal market economies', like Britain and the USA, trade unions can still count on institutionalised partnership relations in the 'coordinated' market economies, like Germany and partly Italy (Soskice, 1999; Thelen, 2001). In terms of membership problems, Nordic and Belgian union movements were found to withstand the socio-economic changes and flexibilisation pressures of the 1980s better than others; they have continued to grow into the 1990s and have higher levels of organisation than elsewhere in Europe (Blaschke, 2000; Ebbinghaus and Visser, 1999). Institutionalist studies stress the importance of industrial relations and welfare state regimes for explaining cross-national differences in union density as well as its growth or decline prospects (Wallerstein and Western, 2000). Most of these empirical studies, however, reach only until the mid-1990s, assuming that the observed trends will continue under largely inert institutional conditions. But there have been surprising turns over the last few years: the Irish, British and Dutch union confederations have seen their membership decline stopped, while in the Nordic countries there are more warning signs of a gradual erosion in unionisation and some challenges to long enjoyed 'union securities'.

Table 1 indicates that the Nordic and Belgian union movements still enjoy the highest level of union density, particularly Sweden, Denmark, and Finland rank at the top, followed by Belgium and Norway. The success of these union movements was attributed to the 'selective incentive' of union-run (so called 'Ghent') unemployment insurance (Rothstein, 1992; Western, 1998) as well as a combination of centralised and decentralised union activities and better union access to workplaces (Hancké, 1993; Kjellberg, 2000). While these unions continued to grow in the early 1990s, over the last years, they experienced relative decline, though not as rapidly as in Germany or Austria. Despite rising membership figures, British and Irish unions have fallen behind employment growth and their relative declines range in the middle. The Netherlands shows a slight decline, Italy some moderate erosion, and Portugal probably considerable decline, while for France, Spain and Greece unionisation levels remained very low and trends remain inconsistent during the 1990s. Hence, based on the trends of the late 1990s, we have to acknowledge that membership decline became more widespread across Europe, though still at significantly different levels. Moreover, union-led unemployment insurance seems no longer able to protect union movements from decline, while improved labour market conditions and 
Table 1: Union membership and density in Europe, 1990-2000

\begin{tabular}{|c|c|c|c|c|c|c|c|c|c|c|c|}
\hline & \multicolumn{2}{|c|}{$\begin{array}{l}\text { Total membership } \\
\text { annual change }(\%)\end{array}$} & \multirow{2}{*}{$\begin{array}{c}\text { Women (\%) } \\
2000\end{array}$} & \multirow{2}{*}{$\begin{array}{l}\text { Non- } \\
\text { actives (\%) } \\
\text { 1990s }\end{array}$} & \multicolumn{3}{|c|}{ Net union density level (\%) } & \multicolumn{2}{|c|}{$\begin{array}{l}\text { Net union density } \\
\text { annual change }(\%)\end{array}$} & \multirow{2}{*}{$\begin{array}{c}\text { Women/ } \\
\text { men } \\
\text { ratio } \\
1990 \mathrm{~s}\end{array}$} & \multirow{2}{*}{$\begin{array}{l}\text { Public/ } \\
\text { private } \\
\text { ratio } \\
1990 \mathrm{~s}\end{array}$} \\
\hline & 1999-95 & 1995-00 & & & 1990 & 1995 & 2000 & 1990-95 & 1995-00 & & \\
\hline Denmark & +0.8 & -0.8 & 50 & 9 & 81 & 86 & 82 & +1.2 & -0.9 & 1.0 & 1.2 \\
\hline Sweden ${ }^{a}$ & +0.1 & -0.4 & 46 & 18 & 80 & 83 & 82 & +0.7 & -0.3 & 1.1 & 1.2 \\
\hline Finland & +2.0 & -0.0 & 54 & 18 & 73 & 80 & 79 & +1.9 & -0.2 & 1.1 & 1.3 \\
\hline Italy & +0.9 & +1.2 & & 51 & 39 & 38 & 37 & -0.5 & -0.8 & & *1.5 \\
\hline Austria & -0.8 & -1.8 & 32 & 17 & 45 & 39 & 35 & -2.8 & -2.1 & 0.6 & 2.3 \\
\hline Portugal & & & & & $* 40$ & *35 & $* 30$ & $*-2.7$ & $*-2.7$ & & 1.2 \\
\hline Greece & & & & & $* 34$ & $* 24$ & 33 & -6.7 & +6.3 & 0.8 & 3.0 \\
\hline Great Britain & -3.7 & +0.0 & 46 & *15 & 38 & 32 & 29 & -3.4 & -1.7 & 1.0 & 3.2 \\
\hline Germany ${ }^{b}$ & -4.9 & -2.9 & 33 & 19 & 33 & 26 & 22 & -5.6 & -3.6 & 0.6 & 2.5 \\
\hline
\end{tabular}

Source: Ebbinghaus and Visser (2000), and own updates.

Notes: *estimated; aSweden: 1999; 'bermany (incl. East): 1991; 'Spain: 1997; 1990s: most recent figure; women share in \% total membership; non-actives (retired people, self-employed, and students) share in \% total membership; annual change: average annual relative growth rate. 
increased partnership initiatives have not (yet) facilitated the hoped for turnaround in unionisation.

\section{Unemployment insurance and union securities}

Since the mid-1970s, long-term mass unemployment has become a major problem of European welfare states; it has also aggravated the membership problems and taxed the bargaining power of unions. The negative impact of long-term unemployment on membership growth was already postulated by business cycle studies before the mass unemployment of the late 1970s (Bain and Elsheikh, 1976), though the proposed relationship proved weak and with considerable lags in statistical models. The unemployed are expected to be more likely to leave the union, while recruitment and retention of members will be more difficult given the potential threat of dismissal by employers. The rise in mass unemployment since the mid-1970s explains some but not the entire decline in overall membership, and not much of cross-national variations. ${ }^{1}$

Under some conditions, unemployment may not hurt but rather help membership mobilization. As several comparative studies have shown, union-led unemployment insurance common in Denmark, Finland, Sweden (and partly Belgium) provides a selective incentive to join and stay in a union (Rothstein, 1992; Western, 1998). Even though there is no legal obligation, potential members perceive such a link. ${ }^{2}$ But involvement by unions in social insurance is not always a union security, thus in France and the Netherlands, unemployment or early retirement schemes jointly run by the social partners cannot provide a 'club good' since non-members are also covered under collective agreements. While union movements with 'Ghent' systems have indeed achieved high union density levels and continued to grow into the early 1990s (Ebbinghaus and Visser, 1999; Golden et al., 1999), membership stagnated or even declined in the late 1990s (see Table 1). Moreover, this 'union security' may not last forever. The increased costs of union-run unemployment and early retirement schemes (as in Denmark) entail financial and political risks. These voluntary schemes are heavily subsidised by the state (or by mandatory employer contributions), while only the administrative costs are borne by membership dues. The Nordic governments, facing exceptionally high unemployment in the early 1990s, introduced costsaving measures or attempted to undermine the union-run unemployment schemeas recently occurred in Denmark. ${ }^{3}$

\section{The uncertain future of the public sector stronghold}

The public sector remains among the best-organised sectors, despite efforts towards privatisation, public sector spending cuts, and new public management methods. In the Nordic states (Denmark, Finland, and Sweden), public sector unionisation (9095\%) is today somewhat higher than in the industrial sector (85-90\%) and appreciably higher than the private service sector (around 70-75\%). Since unemployment is less of a risk to public employees and Norway has no Ghent system, other factors must

\footnotetext{
${ }^{1}$ A recent example is the dramatic membership loss after German unification due to massive downsizing in East Germany: many previously well organized women and older workers were forced out of employment, and young people were disillusioned by lack of apprenticeships and job opportunities (Ebbinghaus, 2002). However, older employees tended to stay in the union in the hope that their organisations can protect their employment rights or at least negotiate social plans in case of downsizing.

${ }^{2}$ In a similar way, Belgian unions are involved in administrating public benefits: they are in charge of mutual sickness funds, and in some sectors negotiate occupational benefits for members only (Van Gyes, De Witte and van der Hallen, 2000).

${ }^{3}$ Recently, Denmark's new conservative-liberal government introduced a cross-sector state unemployment insurance in competition with existing union-run funds, including the Christian union fund which thus far has successfully competed with lower membership fees (EIRO: DK0112147F, DK0204101N).
} 
contribute to the high unionisation rate in the public sector, such as union recognition and bureaucratic structures. While the public/private gap is relatively small in the high-density countries, unionisation in the public sector is much higher than in the market sector, especially in private services, in the countries with overall lower union density. A good example is Britain. According to the Labour Force Survey, unionisation is still three times higher in the public $(60 \%)$ than in the private sector $(19 \%) .{ }^{4}$ Also on the Continent, the public/private gap in unionisation is significant, particularly in countries with hostile private employers and more benevolent central and lower level governments. With the exception of Italy, Ireland, and Portugal, all other continental European unions in the public sector enjoy membership mobilisation at least twice the level of the market sector.

Many factors are conducive to better recruitment conditions in the public sector (Keller, 2001): public employers are more likely to recognize unions and accept union membership across all levels, collectively regulated advancement and pay schemes are more common, bureaucratization is on average higher, and unions have more say in staff policies. In addition to the role as regulator of employment relations, the welfare state as employer has a major impact on national labour relations, often providing 'good practices' and remaining a stronghold for union movements (Traxler, 1999). Where overall unionisation is relatively low and declining, union movements thus become increasingly dependent on the better labour relations in the public sector. The growth to limits of today's welfare states as well as increased privatisation, decentralisation, and public management increasingly undermine this traditional power base. A change in government to New Labour in Britain had not stopped the modernization process, and after its reelection in 2001, public sector reform remains a contentious issue (Bach, 2002). In fact, attempts at welfare retrenchment had a mobilising effect in the public sector across Europe, at times leading to major strikes. In order to circumvent opposition, some governments have sought to negotiate the public sector reforms (Casey and Gold, 2000; Fajertag and Pochet, 2000). Yet in most European countries, pay development in the (local) public sector have been in line or below the private sector over the last two years (2000-01), except in Italy, Ireland, Sweden, Finland and probably France, where public sector unions have negotiated considerably higher pay rises than the productive sector.

\section{Female representation and 'mainstreaming' bargaining policies}

A major long-term change, some have called it the 'most difficult revolution' (Cook, Lorwin and Daniels, 1992), has been the promotion of female participation in union movements. The share among union membership increased in all EU countries and Norway over the last few decades, but there are wide North-South differences in female labour force participation, union membership, and union density. In Nordic welfare states, women are not only as likely to be working as men, they are even more likely to join a union today (see Table 1). Because of high employment and membership rates, Nordic women have more or less achieved parity in overall membership with their male colleagues; they are in a majority position in many public sector and private service sector organisations. Similarly, given relatively high female participation and similar levels of union density in Britain and Ireland, women represent $45 \%$ of union membership in TUC and ICTU, respectively.

On the other hand, female labour force participation, union density, and member-

\footnotetext{
${ }^{4}$ The public/private difference holds also in individual sectors, such as transport and communication: $75 \%$ vs. $36 \%$, education: $58 \%$ vs. $26 \%$ (DTI, 2001). However, increased privatisation has contributed to the overall decline in British union density, although the main national membership decline occurred among male workers (from $44 \%$ in 1989 to $32 \%$ in 2000) and in production (from $45 \%$ to $29 \%$ ). Nevertheless, union density declined by one quarter over the 1990 s in the previously sheltered public sectors of utility, transport and communication, and health services.
} 
ship remain much lower in Continental Europe. ${ }^{5}$ In Germany, Austria, Belgium, and the Netherlands, the likelihood to be organised is 20-40\% lower for women than for men. Only every fourth Belgian and Dutch member and every third German and Austrian member is a woman. This gender gap is even wider in Southern Europe, though membership figures are difficult to obtain, which may be indicative of underdeveloped gender policies. Even during the last decade, in comparison to their membership share, women remained underrepresented on the main executive committees of most union confederations, except in few cases, such as French CFDT and Italian CGIL, which had applied quota representation (Curtin, 1999; Garcia, 2000). Beside CFDT and its Belgian socialist sister organisation, two Nordic union confederations with strong blue-collar Social-democratic traditions have also elected female presidents: Swedish LO in 2000 and Norwegian LO in 2001.

At the European level, representation of women has been rather slow, given the large differences across European Trade Union Confederation's (ETUC) member organisations (Garcia, 2000), but some progress was made at ETUC Congress 1991 with ex officio representation of the advisory Women Committee. In recent years, womens' interests were directly affected by several EU-level social policy activities, in particular the framework agreements on parental leave (1995) and on part-time (1997) as well as EU policy initiatives and European Court of Justice decisions on equal opportunity. The Swedish EU presidency in early 2001 was an opportunity for the governing Swedish Social-Democratic government to advance gender mainstreaming-not only at the national level, but also at the European level.

Gender pay differences are still around 15-20\% in Nordic countries, Ireland, France and Benelux, and even higher in the other continental European countries and the United Kingdom, which cannot be attributed to gender related differences in employment patterns only. Indeed, governments have thus far focused less on equal pay issues than on formal anti-discrimination policies and promotion of female employment, while the collective bargaining partners were less willing to renegotiate the wage structure than to push for general pay increases. 'As a matter of fact, women are largely absent from the collective bargaining process, and the content of agreements at the national level remains male-oriented (Bergamaschi, 2000: 172)'. ${ }^{6}$ In countries with social concertation on income policies, such as Finland, Belgium or Ireland, gender equality issues are more likely to be discussed, while in countries with sectoral or decentralized bargaining, unions seem to leave gender equality issues to government policies.

\section{The ageing of union membership and interest politics}

Over the last years, unions have become major proponents in the debate on the restructuring of welfare states in Europe. At national and EU levels, reforms of payas-you go pension systems and a reversal of early retirement are put forward as responses to current and future fiscal problems, the demographic 'time-bomb', and the low overall employment rates in most parts of Europe. Ageing has also had its impact on most trade unions' membership base and has shaped their interest politics. Most striking is the role of pensioners in the Italian union movement (Chiarini, 1999; Rosanelli and Wolf, 1994), where every second member has retired from the labour force (see Table 1). ${ }^{7}$ Despite a lower membership share in France, pension politics

\footnotetext{
${ }^{5}$ Continental Europe's lower employment rate reflects not merely societal differences but is also the result of conservative welfare regimes that did not facilitate combining work and family responsibilities and provided less employment opportunities in public services than did Nordic welfare states (Daly, 2000; Esping-Andersen, 1999).

${ }^{6} \mathrm{~A}$ rare exception is the Finnish framework agreement 2000-01 (FI0012170F), which provides for additional pay increases for the improvement of female and low skilled workers' income.

${ }^{7}$ Each of the three Italian union confederations has a separate pensioner organisation (SPI-CGIL, FNP-CISL, UILP), and their share of pensioners has increased from 10\% in 1970 to $18 \%$ in 1980 and then rapidly to 39\% in 1990, reaching 49\% in 1997 (Ebbinghaus and Visser, 2000). According to survey results, more than $20 \%$ of all French unionists were pensioners in 1996/97, twice as many as in 1979/80 (INSEE, Doc. 9954, 1999). The share of membership of non-active (including also some other
} 
has a high mobilizing potential, especially among public employees, as indicated by the 1995 strike wave against the Juppé government's cuts of public employee pensions, although this had been imposed on private employees two years earlier (Ebbinghaus and Hassel, 2000). In Continental Europe, pensioners represent a substantial share of overall union membership, particularly in the public sector and in mining (Ebbinghaus and Visser, 2000). But, in contrast to the more militant Southern European trade unions, other continental European union movements rely on pressure group politics and their positions in the self-administered social insurance bodies to advance their interests. And British, Irish and Nordic unions customarily have a workplace orientation focusing on active members, while allied interest groupings provide the main political and social organisation for pensioners. ${ }^{8}$ Whereas British and Irish unions have more limited involvement as a pressure group in public pension politics and hardly play a role in employer-provided occupational pensions, Nordic unions are regularly consulted on public policy, though the competing unions do not always agree on social policy issues.

Unions remain more ambivalent about the organisation and representation of pensioners' interests than is often assumed when looking merely at the number of pensioners. The reluctant acknowledgment of pension interest is also evident at the European level. The European Federation of Retired and Elderly Persons (known by its French acronym: FERPA), was recognised by ETUC but denied the status of European Industry Federation. While the TUC and Italian unions have been active within FERPA since its foundation in 1992, the German and Nordic unions remained sceptical. With the exception of Italy, most unions have not sought to organize the pensioners to the same degree as those still active in the labour market. Indeed, the older working age groups (45-64), those that expect to retire within the next few years, are the best-represented group among members, delegates, and officials in most union movements. ${ }^{9}$ Thus, it is less the membership share of pensioners, but rather the strong unionisation among workers with seniority rights that shifts the balance towards a defence of the status quo (Brugiavini et al., 2001).

\section{Missing youth-the union movement's bleak future?}

The ageing of union membership is not merely the result of demographic shifts; it also results from the failure to mobilize young people. Survey research shows that the likelihood of joining a union decreases and recruitment conditions are unlikely to improve in the future (Klandermanns and Visser, 1995). Today's low mobilisation will thus have consequences for decades to come, especially since the well organised cohorts will soon retire. Certainly, the same structural and cyclical factors explain some of the decline in youth as in overall density rates. Compared to earlier periods

\footnotetext{
groups) is relatively similar in the Benelux and German speaking countries: Austria (ÖGB 1994: 17\%), Belgium (CSC/ACV 1995: 18\%), Germany (1998: 19\%), and the Netherlands (1998: 19\%) (Ebbinghaus and Visser, 2000).

${ }^{8}$ The British Pensioners and Trade Union Association represents since 1972 retired members associations of TUC unions (about 100,000 members or 15\%), and these are associated with the National Pensioners Convention, the main umbrella pressure group defending the rights of about 1.5 million pensioners (Ginn and Arber, 1999). The share of non-active members in Nordic unions not only includes retired members: Denmark (1997: 9\%, LO 14\%), Finland (1989: 8\%), Sweden (1998 LO: 13\%, TCO: $15 \%$, SACO: $26 \%$, incl. students), Norway (1995, incl. self-employed and students: 24\%) (Ebbinghaus and Visser, 2000). The more important pressure groups and social organisation are the separate pensioner organisations, informally tied to the Social Democratic Party and LO unions: Aeldere Mobilisieringen in Denmark, PRO in Sweden (Walker and Naegele, 1999).

${ }^{9}$ According to the Dutch labour force survey (1999) the highest union density (39\%) occurs in the age group 45-65, compared to $27 \%$ of those of working age still employed (age 15-65) (www.cbs.nl). In Britain, membership is most prevalent in the age group (40-49), followed particularly by men in the age group above 50 (DTI, 2001). In France, around 70\% of all those organised in 'syndicats' (including self-employed) were 40 years or older in 1996/97 compared to 48\% in 1979/80 (INSEE, Doc. 9954, 1999). In well-organised Sweden, the differences are less important but there is a difference between $45-64(90.6 \%)$ and the overall level (84.7\%) (www.lo.se).
} 
and older age groups, today's youth face higher risks of joblessness (especially in Southern Europe), more problems to finding an apprenticeship, engage more frequently and longer in tertiary education, obtain more part-time and atypical contracts, and increasingly work in white-collar and service sector jobs. In countries with low or declining membership trends, the age gap is particularly pronounced. In the well organised Nordic and Belgian union movements, which provide strong selective incentives and workplace representation, youth membership is relatively high but still lower than the national average. ${ }^{10}$

The low membership among young workers should cause concern about the future membership development. For many of these young people, unions seem to be rather old-fashioned movements that are certainly less attractive than 'new' social movements and 'fun' leisure activities. Moreover, the majority of union members, congress delegates, and union officials seem to be older than '40-something'. Since current young cohorts are relatively small, union officials may not see the immediate effect of recruitment efforts, though this reinforces the problem of low representation. In countries where youth unemployment, atypical work, and low levels of training are particular problems, young people will be less willing to commit themselves to longterm membership. Thus in Southern Europe, where segmented labour markets provide few opportunities to young people (Esping-Andersen, 2000), alienation from union policies favouring older workers might be highest. For instance, in order to win the consent of the trade unions (and the membership referendum), the Italian pension reform of 1995 used grandfather rules to protect the interests of older workers, mainly affecting the younger cohorts (Regini and Regalia, 1997). The search policies for the young requires new ideas and special recruitment drives among students and the first-job-seekers. ${ }^{11}$

\section{The organizational challenges to the social partners}

\section{Adapting union organisations to the new challenges}

As a response to the financial difficulties caused by declining membership and ongoing economic restructuring, many unions have engaged in mergers in recent years (Waddington, 2001). The largest merger, with nearly 3 million members, occurred with the founding of Germany's largest union Ver.di (Vereinigte Dienstleistungsgewerkschaft-the Unified Service Sector Union) in March 2001, amalgamating four DGB service (and media) sector unions and DAG, a white-collar general union that had remained outside the main confederation after its founding in 1949. In addition, two merger plans in Austria and Britain are striking since they combine manufacturing and white-collar general unions and thus blur traditional sectoral and occupational divisions. After successful membership ballots, the Amalgamated Engineering and

\footnotetext{
${ }^{10}$ Membership among young people is also difficult to obtain; only few unions report this regularly and survey results are available for very few countries. In Great Britain, $6 \%$ of employees under 20 years and 19\% of those aged 20-29 are organised, compared to the overall rate of $29 \%$ and $31 \%$ of those aged 30-39 (LFS 2000). In Germany, membership of young people (16-25) within the DGB dropped considerably from $15 \%$ in the early 1980 s to about $5 \%$ today, and DGB's youth density levels receded after unification from $20 \%$ in 1991 to $10 \%$ in 2000 , while DGB's net density rate (excluding pensioners) dropped during the same period from $28 \%$ to 17\% (Ebbinghaus, 2002). In the Netherlands, union density among young people (15-25) is only $12 \%$, three times less than among older workers (45-64) in 1999 (www.cbs.nl). Two Belgian surveys of employees in Flanders find surprisingly similar union density rates across different age groups in the 1990s (Van Gyes et al., 2000). Swedish union density for the very young (16-24) is considerably lower (47\%) and among employees aged 25-29 somewhat lower (76\%) than for all age groups (81\%) in 1999. Moreover, the rates have dropped for those aged 16-24 by 16, for those aged 25-29 by 7 percentage points over the last twelve years, while the overall rate nearly stayed the same (Kjellberg, 2000).

${ }^{11}$ For instance, the Danish LO has recently proposed 'flexible working time accounts' that provide leave over the lifetime; this is thought to be more attractive for younger workers (DK0101110N). Given the longer educational period and higher participation in tertiary education, the Scandinavian professional associations seem particularly keen in binding members already as students.
} 
Electrical Union (AEEU) and Manufacturing Science Finance (MFS) merged to form 'Amicus', on 1 January 2002. It is TUC's second largest union (about one million members) and the largest Labour Party affiliate. During 2001, the largest Austrian union, the private sector white-collar union GPA (Gewerkschaft der Privatangestellten) thwarted the restructuring plans of the confederation, which would have entailed a break up of GPA, by merger with GMT (Gewerkschaft Metall-Textil), the recently amalgamated blue-collar workers' union in metal and textile industries. Although the Austrian union structure thus far resembled the German one (industrial unions plus a white-collar general union), the proposed merger will lead to very different 'power poles': private sector vs. public sector unions in Austria, industrial vs. service sector unions in Germany. In Sweden, the largest union (Kummunal) absorbed the agricultural union in January 2002, while other blue-collar unions within the main confederation LO have recently discussed merger plans between unions for communication employees, graphical workers and electricians as well as between the commercial workers and transport workers unions.

Restructuring also took place in other countries, particularly in the service sectors, though not all attempts were successful. In Belgium, the transport and communication workers unions within the Christian union movement merged to form CSC/ACV-Transcom in April 2001. For Finland, 2001 became a major year of reorganization, with two large-scale mergers and merger talks between the major confederations for blue-collar workers (SAK), white-collar employees (STTK) and academically trained professionals (Akava). ${ }^{12}$ Two Norwegian teacher unions also formed a new union and helped found a new public servant federation. ${ }^{13}$ However, some efforts at restructuring also failed. The 'TRIO-project' to create a Swedish service sector union out of four TCO white-collar unions came to a halt after the refusal of the commercial employee union at the end of 2001. Similarly, the merger of two teachers unions within the Danish white-collar federation FTF did not materialize. More importantly, two membership votes rejected the merger plans between the metal workers union and electricians unions within the Danish main union confederation LO. These failures impede efforts to rationalize the fragmented Danish union structure-over a hundred unions, from large general to small professional unions. The general trend towards more concentration, which seems more acute among union movements in the North than in the South of Europe, also has profound repercussions for the relationship between the confederation and its ever fewer, larger affiliates (Waddington, 2001). Hence, while the role of peak associations may have been enhanced thorough social concertation on income policies and welfare reform in several European countries, the organisational restructuring tends to pull the power balance from the central to the sectoral organisations.

\section{Employer organisation, union recognition and bargaining coverage}

Trade unions cannot be indifferent to their opponents' organisational strengths and weaknesses: the associational structures of employers facilitate or hamper bargaining centralisation, their degree of organisation largely determines bargaining coverage, and their policies towards union recognition have major repercussions, especially at workplace level. On the side of capital, mergers occur not only between companies but also between sector-wide employer associations, thereby undermining the

\footnotetext{
${ }^{12}$ Only half a year after the formation of Finland's second largest union PAM (Palvelualojen Ammattilitto), which combined four blue-collar service sector unions affiliated to SAK in November 2000, four unions within STTK merged to form Toimmihenkilöunioni (TU), Finland's fourth largest union in May 2001.

${ }^{13}$ The new teacher union (Utdanningsforbundet), was formed by merger in January 2002, becoming a founding member of the new public servant federation UHO (Utdanningsgruppenes Hovedorganisasjon). UHO fills in for the former confederation of professional associations (AF), disbanded in 2000 after failed merger talks with its competitor (YS).
} 
traditional division of labour between industrial unions. Over the last years, fusions of employer and trade associations and mergers among sectoral employer associations, particularly in service sectors, have made sector-level negotiations, not central bargaining, more likely. Having abolished its bargaining department in 1990, the Swedish employer association (SAF) merged in 2001 with the peak trade association to form the Confederation of Swedish Enterprise (Svenskt Näringsliv or SN) after nearly a century of division of labour. Within the EU, only the German peak employer organisation is truly independent from the peak trade association, while the other remaining peak employer association (Danish DA) includes among its members mixed associations such as the Confederation of Danish Industries (DI). Plans for a merger of Danish service sector employers to form SE (ServiceErhvervene), aimed at counterbalancing DI's strength within DA, further blur the outdated division of labour between employer and trade interests.

Voluntary employer associations face considerable membership problems. Previously affiliated firms tend to exit as they seek to escape sector-level agreements, and newly formed firms, particularly smaller firms in the service sector, tend to remain unorganised. An example is the erosion of the German bargaining model after unification: employer organisations and unions see bargaining coverage slip away not only in the East but also increasingly in the West. ${ }^{14}$ A special case is Austria, which enforces mandatory membership in the Chamber of Commerce, however, following a long debate about its statutory role, the mandatory dues payments will be cut by a third over the next years, limiting the resources for negotiating collective agreements, consultation on social and economic legislation, and trade interests lobbying.

The decline in employer association membership (and the reduction of their functions) should worry trade unions as much as their own membership decline, since this has repercussions for overall bargaining coverage, unless state intervention extends (erga omnes) collective agreements to non-organised firms and members (Traxler, 1999). Compared to the early 1990s (Traxler, 2000), coverage of employer associations, whether measured by firms or employment, has declined further in nearly all countries, though comparable data is even more difficult to obtain than for trade unions. 'Excess coverage' beyond the extent of union and employer membership is particularly high in countries with erga omnes extension of collective agreements (Belgium, France, Greece, Portugal, and Spain), while in the Nordic countries both high levels of union density and well-organised employer associations guarantee widespread bargaining coverage (Calmfors et al., 2001). Particularly in the absence of institutionalised union securities, trade unions are thus dependent on the organisational success and membership compliance of employer organisations.

Within the EU, Britain and Ireland have the lowest coverage rate due to widespread decentralisation and non-recognition in addition to low levels of employer organisation and union density. In both countries, bargaining coverage and access to the workplace for unions depend primarily on union recognition by individual employers. In a 2002 report, UK's Trades Union Congress (TUC) welcomed the 1999 Employment Relations Act, though calling upon the government to eliminate the $40 \%$ quorum hurdle. The impact of the new law in terms of employment was still relatively small: less than $10 \%$ of the first year's applications to the Central Arbitration Committee were for firms with more than 500 employees, though some are of symbolic importance. Nevertheless, one can doubt whether the statutory recognition procedure is useful in stemming the tide of union derecognition. In contrast to information and consultation procedures as promoted by EU law or on the Continent, British recognition procedures do not advance 'social dialogue' beyond those work-

\footnotetext{
${ }^{14}$ Bargaining coverage decline in the East from $56 \%$ in 1996 to $45 \%$ of employees in 2000, but also in the West from $72 \%$ in 1995 to $62 \%$ in 2000 (IAB-Betriebspanels, EIRR 337, 2002: 23). Since smaller firms are least organised, more than $70 \%$ of firms in the East and $50 \%$ in the West are not bound by a sectoral or company agreement in 2000, though about $40 \%$ of these unaffiliated firms voluntarily apply the collective agreement in their sector or area.
} 
places where unions are well represented since consultation practices remain voluntary (Brown et al., 2001; Terry, 1999).

Similar structural changes unfavourable to union organizing have led to increased non-recognition in Ireland, reinforced by government action seeking to attract foreign investors. This applies particularly to new US multinationals, which pursue antiunion HRM policies (Roche, 2001). Thus, Ireland's tripartite high-level group on union recognition recommended a more voluntarist route in 1999, leading to the Code of Good Practice on Voluntary Dispute Resolution. ${ }^{15}$ The Irish Confederation of Trade Unions (ICTU) has criticised the long review process and lack of a ruling on recognition, while employers-particularly US multinationals-oppose statutory recognition. As in Britain, unions and employers in Ireland have opposing views over the implementation of the EU Directive on information and consultation: the employers favouring the least restrictive application that also allows 'direct communication' between employers and employees, while the unions hope for future improvements to bring similar advantages, such as works council practices on the Continent.

\section{The changing role of unions in welfare state reform}

\section{Gaining a new bargaining role in occupational welfare policies}

The involvement of unions in the social policy area goes beyond central tripartite pacts and participation in self-governing bodies of national social insurance schemes. With the increased importance of private pensions in addition to mandatory state pensions, trade unions have gained or enhanced their collective bargaining role in this area. Besides the Netherlands and France, negotiations on second tier supplementary pensions have a long tradition in Sweden. The Swedish social partners had established four main occupational schemes as early as the 1970s (Wadensjö, 1997). Parallel to the reform of the state pension scheme in the late 1990s, the social partners began to negotiate changes in the funding of these negotiated occupational pensions. In addition, recent EU directives on part-time and temporary contracts make it necessary to remove discriminatory rules in supplementary pensions. This led to the settlement of two agreements for national and subnational government employees in 2001. However, the social partners are not always able to come to an agreement, as is the case for white-collar occupational pensions over the last years. Governments may then be tempted to intervene into areas that are traditionally settled by collective bargaining. ${ }^{16}$

Even in countries where unions had no tradition of negotiating private pensions, they have come to seize on the opportunity to enhance their role and provide some collective regulation of state-imposed privatisation. Most notably, the 2001 German pension reform, which introduced new voluntary private pension funds to fill the gap due to cuts in the public benefits, has led to collective agreements on occupational pension schemes and wage-into-contribution-conversion arrangements in such industries as construction, chemicals, and metal (Bispinck, 2002). However, voluntary supplementary private pensions introduced in Italy in the mid-1990s have not proven to be very successful and Italian unions are divided about the future course.

The growth of supplementary schemes and coverage not only depends on the collective bargaining partners but also on government policy, such as favourable tax

\footnotetext{
${ }^{15}$ Since May 2000, employers and trade unions can seek non-binding conciliation on the 'right to bargain' by the Labour Relations Commission (LRC) and since June 2001 can invoke a 'fall-back' provision with the Labour Court in the case of employer intransigence (IE0201260F).

${ }^{16}$ For instance, the Swedish legislator provided the right to employees to continue employment until age 67, annulling provisions in sectoral collective agreements that enforce mandatory retirement at age 65 (SE0103186F). The two main union confederations for blue-collar workers (LO) and whitecollar employees (TCO) have called upon the International Labour Organisation (ILO) to sanction this breach of an ILO convention (SE0201113N).
} 
treatment and legislation supporting collective bargaining solutions as well as the sufficiency of public pension provisions. In respect to second-tier supplementary pensions, French and Dutch social partners have, for instance, applied contrasting approaches to the coverage problem. In France, the collectively negotiated pay-asyou-go schemes were made mandatory by the state, while the Dutch social partners in the Social-Economic Council (SER) opposed government plans to extend coverage erga omnes to the $10 \%$ non-covered employees. On the other hand, French unions and the political Left remain largely opposed to plans introducing supplementary private pension funds à l'anglaise, while the Dutch social partners increasingly convert their early retirement plans from pay-as-you go to funded defined contribution plans.

Although occupational pension funds have a long tradition in the UK and Ireland, coverage is lower than in the Northern European countries, including Sweden, Denmark, Germany, and the Netherlands (Rein and Wadensjö, 1997). Moreover, trade unions have not played a major role in negotiating occupational pensions, which remain largely a voluntary employer initiative and managed by an independent pension fund with no or limited union representation. The Labour governments' Stakeholder Pension Scheme (SPS) provides more affordable voluntary pensions to low income groups since April 2001. However, there is no obligation on employer contributions and little scope for bargaining on this issue. For the British union movement that traditionally defended basic pension and state earnings-related pensions against retrenchment policies of the previous Conservative governments, the participation in the Labour government's initiative is nevertheless a major change in policy. ${ }^{17}$

\section{Social partnership institutions under political pressure}

Trade unions have become more dependent on their institutionalized roles in current welfare states. However, their legitimate role in them has been increasingly questioned. Trade unions will have to define a strategy in respect to current efforts at welfare reform. The challenges to institutionalized social partnerships can be studied in the case of recent events. Large-scale opposition to social security and labour market reforms is no longer limited to Conservative governments as in the mid-1990s under the Juppé government in France and the Berlusconi government in Italy (Ebbinghaus and Hassel, 2000).

Comparative studies show the French unions to be the least organised in Europe: they organise less than 10\% of all employees (Ebbinghaus and Visser, 2000), but gain institutional power through their role in elected workplace representative bodies and in the self-administration of social insurance (Palier, 2002). French unions have become dependent on outside funding or secondment of union officials provided by the state, employers and social insurance administration-an issue criticised by the employers and hotly debated in public over the last years. Following the lost battle over 35 hours legislation imposed by the Socialist government, French employers transformed their peak association, giving it a more 'activist' name (MEDEF, Mouvement des entreprises de France or Movement of French enterprises) in October 1998. A year later, in November 1999, the new MEDEF leadership declared a 'refondation sociale', a general overhaul of industrial relations and social partnership arrangements. MEDEF threatened to withdraw from self-administration if reforms could not be agreed upon. By the end of 2001, the French employers associations and unions (though not always all of them) signed four agreements on supplementary pension schemes, unemployment insurance funds, consultation on health and safety at work and collective bargaining procedures. On other issues, including sickness insurance and training, the social partners could not reach an agreement and the main employer

\footnotetext{
${ }_{17}$ The TUC has taken the opportunity to set-up its own stakeholder pension fund, targeted at about one million union members without occupational pensions and also at employers who find the obligation to set up a fund for their employees too burdensome (UK0103119F).
} 
organisations retreated from several social security boards. The unions remain split into two camps: the more moderate unions (led by CFDT) that seek cooperation with the employers and the more radical unions (CGT, CGT-FO) that defend the status quo of worker rights. A new proposal put forward by MEDEF in November 2001 calls for major reforms introducing 'structured competition' for sickness insurance, a reform of first and second tier pensions, and an end to employer financing of family policies. However, the Socialist government was unwilling to take any steps in this respect before the presidential elections. The success of the Right in the parliamentary elections after President Chirac's re-election in May 2002 will give the Right a mandate to attempt new reforms after the unsuccessful effort in 1995.

The consensual post-war institutions of Austrian social partnership also came under pressure, yet not so much by employer action but through the entry of the right-wing Freedom Party of Austria (FPO) into the centre-right coalition government in February 2000. A commission report on social security reform in September 2000 found mixed reception by the social partners, the unions opposing the reform and the employers asking for further cuts. Despite union protests, the government coalition in September 2000 enacted a major pension reform that curtails early retirement through higher age limits and benefit cuts. A year later, the government imposed a change in the administration of the social insurance system that guarantees a seat to the FPÖ-affiliated faction. This was seen as major assault on social partnership and a national union ballot for the first time called for protest action. ${ }^{18}$

After the election of the Berlusconi right-wing government in May 2001, wideranging reforms in industrial relations and social policy were announced in a White Paper in October 2001. All three main trade union movements criticised the proposed reforms in the area of labour market, in particular the alteration of the 1970 Worker Statutes dismissal regulation, and called for strike action that occurred at the beginning of 2002. Already the previous Berlusconi government had a disastrous clash with unions on pension policy, which led to a protest wave and the retreat of the government in 1994 (Regini, 1997). The current government tried to engage in social dialogue (at arm's length), but this broke down when the government announced the labour market reforms. At times, inter-union splits make a unified opposition to government policies rather difficult, though the strike action in April 2002 has united the unions again. ${ }^{19}$

While in Italy major social concertation during the 1990s had occurred only at times when the Right was not in government. In Spain, it was the Conservative government that concluded the 'Toledo Pacts' on social security reforms in 1996. The preceding Socialist government had let concertation decline over its long tenure (Hamann, 2001). However, during 2001, the conservative government's efforts at

\footnotetext{
18 The Austrian trade union confederation ÖGB (Österreichischer Gewerkschaftsbund) successfully called a national ballot for strike action ( $56.6 \%$ in favour), the first time ever in a country with a hitherto low record of industrial conflict (AT011201F). The disputed representation rule guarantees a seat to the Freedom faction (FA) despite the recent loss in the Chamber of Labour elections (AT-109201F). Although this may seem a rather administrative issue, it is indicative of the break with the consensual tradition in social and economic policy making in Austria and the welfare retrenchment plans of the current government. Nevertheless, the government has delegated some issues, such as the reform of severance pay to the social partners which will increase coverage and improve benefits for those changing jobs (AT0112231).

${ }^{19}$ In spring 2002, after heated debate and the terrorist murder of a government consultant, all three Italian union movements called for a general strike in April 2002 against the right-wing government's labour market and pension reform. An instance of inter-union split occurred when the ex-communist union confederation CGIL left negotiations on the implementation of the EU Directive on fixed-term contracts, while the two other union confederations signed a joint social partner declaration, which liberalizes the previous restrictions on temporary contracts. The government transposed it into law in September 2001. On the other hand, when the main unions are united, they can achieve negotiating successes, as with the recent public sector agreement in February 2002. The agreement sets up a consultation forum for social security reforms for public employees and reaffirms the 1993 agreement on the prerogative of national and local collective bargaining over the unilateral governmental route for public sector employment matters (IT0203102N).
} 
tripartite concertation failed over contentious issues concerning collective bargaining, labour market reform, social security reform, and public sector reform. A significant exception was the Pact on Pensions, which was signed in April 2001 by the employers and ex-Communist CC.OO (Comisiones Obreras), but not Socialist UGT (Unión General de Trabajadores) despite relatively favourable conditions. On the other issues, the government resorted to unilateral measures. Most importantly, it pushed a reform of temporary contracts by law in early 2001 and university reform in late 2001. In neighbouring Portugal, the Socialist government was more successful in striking tripartite agreements on training of young people, improving working conditions, and on reforming pensions in 2001, though the employers abstained from the pension deal and the ex-Communist CGTP union confederation opposed the introduction of optional private pensions.

In Greece, protests against the Socialist government's plans culminated in a oneday general strike in April 2001. In southern European countries, concerted action for defending acquired social rights seems to mobilize worker movements despite their membership weakness and organisational fragmentation. Governments then seem to have the choice between pursuing unilateral reforms that provoke widespread protest and risk implementation problems or negotiating a compromise solution with trade unions that buffers the impact, especially for the core workforce, i.e. male workers with regular employment contracts. Grandfather rules may make such deals tolerable to the core membership of trade unions, and may help to get them through internal decision-making or, as in Italy, through membership ballots (Baccaro, 2000). A more recent example is the Finnish tripartite agreement of November 2001 on the long-term reform of pensions and unemployment insurance, which uses transitional measures and different rules for past and future benefit claims to come to consensus.

In the Netherlands, disability pensions remain a problem despite several major reforms. In 2001, a committee made new recommendations for reintegrating disabled people into work and increasing conditionality of benefits, yet only after long debates and under strong political pressures did the social partners reach a compromise in January 2002. The Dutch social partners' role in governing bodies has come increasingly under criticism. For instance, the liberal party, a member of the current leftliberal government coalition, has openly questioned the representativity of Dutch unions with less than $30 \%$ union density, while the use of sector-wide social funds by the social partners was also discussed in public, resembling the French discussion. Also in the area of labour market policies, the role of the social partners was increasingly questioned. The Netherlands has already reformed its employment services through fostering private employment agencies. In contrast, change has been slow in Germany. A recent scandal of misreporting in March 2002 has not only caused a major reform debate on the future of the Federal Employment Office but also the role the social partners play in it (Trampusch, 2002).

\section{Conclusion: with or against the tide of welfare state reform?}

Trade unions have seen their membership dwindle further. Neither more favourable recognition policies, nor improvements in the labour market have led to a turnaround. Moreover, ageing of membership and lacking support among young people have not spared those union movements with institutionalized 'union securities', such as Ghent unemployment insurance. Although union movements have become more inclusive (about half of union members in Nordic countries or in the British Isles are women); the representation of womens' interests in union decision-making, particularly in collective bargaining policy, still lags behind. Favourable labour relations conditions in the public sector have provided union movements with a stronghold. Welfare state and public sector reforms can mobilize workers in defence of the status quo and they provide also an opportunity to negotiate change for reform-minded unions. Institutionalized involvement in social policy governance, as 
well as union securities provided by the welfare state, can be crucial for additional legitimation and resources at a moment when unions see their membership decline. However, social partnership institutions, as well as the employers as opponents, are changing and this can have negative repercussions on unions' roles in both the bargaining and social policy realms.

In addition to the role social partners have played in negotiating social pacts on income policies since the run up to European Monetary Union during the 1990s (Fajertag and Pochet, 2000; Rhodes, 2001), union movements have also been involved in the politics of welfare state reform (Ebbinghaus and Hassel, 2000; Reynaud, 2000). As the scope for collective bargaining under the conditions of European Monetary Union and international competition is limited, trade union movements could find a renewed role in welfare reform politics. In order to circumvent blockage in political decision-making or implementation, governments seek social concertation in both welfare and labour market policies. With increased privatisation of public welfare benefits, there is increased scope for a new role of unions in negotiating occupational benefits. While some union movements, especially in the Nordic countries, in the Benelux, and in France, have experience in negotiating occupational welfare benefits, this role is relatively new to German and Italian unions, and still relatively unfamiliar to British and Irish unions.

At the same time, the role of the social partners in self-governing bodies of social insurance has come under criticism, particularly in Austria, France, Germany, and the Netherlands. The employers have promoted a major reorganisation of social partnership institutions, particularly in France. Some governments, mainly on the initiative of right or liberal parties, have also challenged the traditional social partnership. Union leaders see these efforts as attacks on post-war social compromises and called for protest strikes, the first such ballot in Austria and the first general strike call for two decades in Italy. Depending on the elections in several European countries during 2002, more governments with critical stances on social partnership may come to power. The increased involvement of unions in social and labour market policy areas may thus come under further pressures, while it seems to be both necessary and promising for a renewal of today's union movements in changing Europe.

Corresponding author: Bernhard Ebbinghaus, Max Planck Institute for the Study of Societies, Paulstr. 3, D-50676 Cologne, Germany. Ebbinghaus@mpi-fg-koeln.mpg.de

\section{References}

Baccaro, L. (2000), 'Negotiating Pension Reform with the Unions: The Italian Experience in European Perspective', in 12th International Conference of Europeanists. Chicago, March 30-April 2, 2000.

Bach, S. (2002), 'Public-sector Employment Relations Reform under Labour: Muddling Through or Modernization?' British Journal of Industrial Relations, 40, 2, 319-99.

Baglioni, G. and C. Crouch (eds.) (1990), European Industrial Relations. The Challenge of Flexibility (London: Sage).

Bain, G. S. and F. Elsheikh (1976), Union Growth and the Business Cycle (London: B. Blackwell).

Bergamaschi, M. (2000), 'The Gender Perspective in the Policies of European Trade Unions', in M. Rossilli (ed.) Gender Policies in the European Union pp. 159-74 (New York: Peter Lang).

Berger, S. and H. Compston (eds.) (2002), Policy Concertation and Social Partnership in Western Europe: Lessons for the 21st Century (New York: Berghahn Books).

Bispinck, R. (2002), 'Tarifpolitischer Jahresbericht 2001: Moderate Lohnabschlüsse plus 'Altersvorsoge", WSI Mitteilungen, 2/2002, 67-76.

Blaschke, S. (2000), 'Union Density and European Integration: Diverging Convergence', European Journal of Industrial Relations, 6, 2, 217-36.

Brown, W., S. Deakin, M. Hudson and C. Pratten (2001), 'The Limits of Statutory Trade Union Recognition', Industrial Relations Journal, 32, 3, 180-94.

Brugiavini, A., B. Ebbinghaus, R. Freeman, P. Garibaldi, B. Holmund, M. Schludi and T. Verdier (2001), 'Part II: What Do Unions Do to the Welfare States?' in T. Boeri, A. Brugiavini and L. Calmfors (eds), The Role of Unions in the Twenty-First Century. A Report to the Fondazione Rodolfo Debenedetti pp. 157-277 (Oxford: Oxford University Press). 
Calmfors, L., A. Booth, M. Burda, D. Checchi, R. Naylor and J. Visser (2001), 'Part I: The Future of Collective Bargaining in Europe', in T. Boeri, A. Brugiavini and L. Calmfors (eds), The Role of Unions in the Twenty-First Century. A Report to the Fondazione Rodolfo Debenedetti pp. 1-134 (Oxford: Oxford University Press).

Casey, B. and M. Gold (2000), Social Partnership and Economic Performance: The Case of Europe (Cheltenham, UK: Edward Elgar).

Chiarini, B. (1999), 'The Composition of Union Membership: The Role of Pensioners in Italy', British Journal of Industrial Relations, 37, 4, 577-600.

Cook, A. H., V. R. Lorwin and A. K. Daniels (1992), The Most Difficult Revolution. Women and Trade Unions (Ithaca: Cornell University).

Curtin, J. (1999), Women and Trade Unions: A Comparative Perspective (Aldershot: Ashgate).

Daly, M. (2000), 'A Fine Balance: Women's Labor Market Participation in International Comparison', in F. W. Scharpf and V. Schmidt (eds), Welfare and Work in the Open Economy. Vol. II pp. 467-510 (Oxford: Oxford University Press).

de la Porte, C. (2001), 'The Complex Soft Government Technique and the Brittle Consensus in European Social Protection', in E. Gabaglio and R. Hoffmann (eds), European Trade Union Yearbook 2000 pp. 293-314 (Brussels: European Trade Union Institute).

DTI (2001), 'Trade Union Membership 1999-2000: An Analysis of Data from the Certification Officer and the Labour Force Survey', Labour Market Trends (Department of Trade and Industry), September, 433-44.

Ebbinghaus, B. (1999), 'Does a European Social Model Exist and Can it Survive?' in G. Huemer, M. Mesch and F. Traxler (eds), The Role of Employer Associations and Labour Unions in the EMU. Institutional Requirements for European Economic Policies pp. 1-26 (Aldershot: Ashgate).

Ebbinghaus, B. (2002), 'Dinosaurier der Dienstleistungsgesellschaft? Der Mitgliederschwund deutscher Gewerkschaften im historischen und internationalen Vergleich', Max Planck Institute (MPIfG, Cologne), Working Paper, 02, 03.

Ebbinghaus, B. and A. Hassel (2000), 'Striking Deals: Concertation in the Reform of Continental European Welfare States', Journal of European Public Policy, 7, 1, 44-62.

Ebbinghaus, B. and J. Visser (1999), 'When Institutions Matter: Union Growth and Decline in Western Europe, 1950-1995', European Sociological Review, 15, 2, 1-24.

Ebbinghaus, B. and J. Visser (2000), Trade Unions in Western Europe since 1945 (Handbook and CDROM) (London: Macmillan).

EIRO (doc.), EIROnline, Dublin Foundation [http://www.eiro.eurofound.ie].

Esping-Andersen, G. (1999), Social Foundations of Postindustrial Economies (Oxford: Oxford University Press).

Esping-Andersen, G. (2000), 'Who is Harmed by Labour Market Regulations? Quantitative Evidence', in G. Esping-Andersen and M. Regini (eds), Why Deregulate Labour Markets? pp. 6698 (Oxford: Oxford University Press).

Fajertag, G. and P. Pochet (eds.) (2000) Social Pacts in Europe: New Dynamics (Brussels: ETUI).

Garcia, A. (2000), 'The 'Second Sex' of European Trade Unionism', in E. Gabaglio and R. Hoffmann (eds), European Trade Union Yearbook 1999 pp. 213-37 (Brussels: European Trade Union Institute).

Ginn, J. and S. Arber (1999), 'The Politics of Old Age in the UK', in A. Walker and G. Naegele (eds), The Politics of Old Age in Europe pp. 152-67 (Buckingham: Open University Press.

Golden, M. A., M. Wallerstein and P. Lange (1999), 'Postwar Trade-Union Organization and Industrial Relations in Twelve Countries', in H. Kitschelt, P. Lange, G. Marks and J. Stephens (eds), Continuity and Change in Contemporary Capitalism pp. 194-230 (New York: Cambridge University Press).

Hamann, K. (2001), 'The Resurgence of National-Level Bargaining: Union Strategies in Spain', Industrial Relations Journal, 32, 2, 154-72.

Hancké, B. (1993), 'Trade Union Membership in Europe 1960-90: Rediscovering Local Unions', British Journal of Industrial Relations, 31, 4, 593-613.

Katz, H. C. (1993), 'The decentralisation of collective bargaining: A literature review and comparative analysis', Industrial \& Labor Relations Review, 47, 1, 3-22.

Keller, B. (2001), 'Employer Associations and Unions in the Public Sector', in C. Dell'Aringa, G. Della Rocca and B. Keller (eds), Strategic Choices in Reforming Public Service Employment: An International Handbook pp. 71-96 (Houndmills-New York: Palgrave).

Kjaergaard, C. and S.-Å. Westphalen (eds.) (2001), From Collective Bargaining to Social Partnerships: New Roles of the Social Partners in Europe (Copenhagen: The Copenhagen Centre).

Kjellberg, A. (2000), 'The Multitude of Challenges Facing Swedish Trade Unions', in J. Waddington and R. Hoffmann (eds), Trade Unions in Europe. Facing Challenges and Searching for Solutions pp. 529-73 (Brussels: ETUI). 
Klandermanns, B. and J. Visser (eds.) (1995), De vakbeweging na de welvaartsstaat (Assen: Van Gorcum).

Palier, B. (2002), Gouverner la sécurité sociale: Les réformes du système français de protection sociale depuis 1945 (Paris: PUF).

Regini, M. (1997), 'Still Engaging in Corporatism? Recent Italian Experience in Comparative Perspective', European Journal of Industrial Relations, 3, 3, 259-78.

Regini, M. and I. Regalia (1997), 'Employers, Unions and the State: The Resurgence of Concertation in Italy?' West European Politics, 20, 1, 210-30.

Rein, M. and E. Wadensjo (eds.) (1997), Enterprise and the Welfare State (Cheltenham, UK: Edward Elgar).

Reynaud, E. (ed.) (2000), Social Dialogue and Pension Reform: United Kingdom, United States, Germany, Japan, Sweden, Italy, Spain (Geneva: International Labour Office).

Rhodes, M. (2001), 'The Political Economy of Social Pacts: 'Competitive Corporatism' and European Welfare Reform', in P. Pierson (ed.) The New Politics of the Welfare State pp. 165-94 (New York: Oxford University Press).

Roche, W. K. (2001), 'Accounting for the Trend in Trade Union Recognition in Ireland', Industrial Relations Journal, 32, 1, 37-54.

Rosanelli, M. and J. Wolf (1994), 'Die italienischen Rentnergewerkschaften', in J. Wolf, M. Kohli and H. Künemund (eds), Alter und gewerkschaftliche Politik: Auf dem Weg zur Rentnergewerkschaft? pp. 97-121 (Köln: Bund-Verlag).

Rothstein, B. (1992), 'Labor-market Institutions and Working-class Strength', in S. Steinmo, K. Thelen and F. Longstreth (eds), Structuring politics: Historical Institutionalism in Comparative Analysis pp. 33-56 (New York: Cambridge University Press).

Scruggs, L. and P. Lange (2002), 'Where Have All the Members Gone? Globalization, Institutions, and Union Density', Journal of Occupational Psychology, 64, 1, 126-53.

Soskice, D. (1999), 'Divergent Production Regimes: Coordinated and Uncoordinated Market Economies in the 1980s and 1990s', in H. Kitschelt, P. Lange, G. Marks and J. Stephens (eds), Continuity and Change in Contemporary Capitalism pp. 101-34 (New York: Cambridge University Press).

Streeck, W. (1999), 'Competitive Solidarity: Rethinking the "European Social Model" ', Max Planck Institute (MPIfG, Cologne), Working Paper, 99/8.

Terry, M. (1999), 'Systems of Collective Employee Representation in Non-Union Firms in the UK', Industrial Relations Journal, 30, 1, 16-.

Thelen, K. (2001), 'Varieties of Labor Politics in the Developed Countries', in P. A. Hall and D. Soskice (eds), Varieties of Capitalism: The Institutional Foundations of Comparative Advantage pp. 71-103 (New York: Oxford University Press).

Trampusch, C. (2002), 'Die Bundesanstalt für Arbeit und das Zusammenwirken von Staat und Verbänden in der Arbeitsmarktpolitik von 1952 bis 2001', Max Planck Institute (MPIfG, Cologne), Working Paper, 02, 5.

Traxler, F. (1999), 'The State in Industrial Relations: A Cross-national Analysis of Developments and Socioeconomic Effects', European Journal of Political Research, 36, 55-85.

Traxler, F. (2000), 'Employers and Employer Organisations in Europe: Membership Strength, Density and Representativeness', Industrial Relations Journal, 31, 4, 308-16.

Traxler, F., S. Blaschke and B. Kittel (2001), National Labour Relations in Internationalized Markets. A Comparative Study of Institutions, Change, and Performance (Oxford: Oxford University Press).

Van Gyes, G., H. De Witte and P. van der Hallen (2000), 'Belgian Trade Unions in the 1990s: Does Strong Today Mean Strong Tomorrow?' in J. Waddington and R. Hoffmann (eds), Trade Unions in Europe. Facing Challenges and Searching for Solutions pp. 105-41 (Brussels: ETUI).

Visser, J. (1991), 'Trends in Trade Union Membership', in OECD Employment Outlook 1991 pp. 97134 (Paris: OECD).

Visser, J. (1998), 'European Trade Unions in the Mid-1990s', in B. Towers and M. Terry (eds), Industrial Relations Journal: European Annual Review 1997 pp. 113-30 (Oxford: Blackwell).

Waddington, J. (2000), 'Towards A Reform Agenda? European Trade Unions in Transition', Industrial Relations Journal, 31, 4, 317-30.

Waddington, J. (2001), 'Articulating Trade Union Organisation for the New Europe?' Industrial Relations Journal, 32, 5, 449-63.

Wadensjö, E. (1997), 'The Welfare Mix in Pension Provisions in Sweden', in M. Rein and E. Wadensjö (eds), Enterprise and the Welfare State pp. 266-308 (Cheltenham, UK: Edward Elgar).

Wadensjö, E. (2000), 'Sweden: Reform of the Public Pension System', in E. Reynaud (ed.) Social Dialogue and Pension Reform pp. 67-80 (Geneva: International Labour Office).

Walker, A. and G. Naegele (eds.) (1999), The Politics of Old Age in Europe (Buckingham: Open University Press). 
Wallerstein, M. and B. Western (2000), 'Unions in Decline? What Has Changed and Why', Annual Review of Political Science, 3, 355-77.

Western, B. (1998), 'Institutions and the Labor Market', in M. C. Brinton and V. Nee (eds), The New Institutionalism in Sociology pp. 224-43 (New York: Russell Sage Foundation). 